\title{
Implementasi bahan ajar hasil pengembangan materi mata kuliah instrumentasi dalam konseling I di Universitas Jambi
}

\author{
Freddi Sarman $^{\left.1^{*}\right)} \&$ Asradi $^{2}$ \\ University of Jambi ${ }^{12}$ \\ *) Alamat korespondensi: Jl. Raya Jambi-Muara Bulian No. Km. 15, Jambi, 36361, Indonesia; E-mail: \\ freddisarman@unja.ac.id
}

\begin{abstract}
Article History:
Received: 19/10/2020;

Revised: 12/06/2021;

Accepted: 21/06/2021;

Published: 30/06/2021.
\end{abstract}

How to cite:

Sarman, F. \& Asradi. (2021). Implementasi bahan ajar hasil pengembangan materi mata kuliah instrumentasi dalam konseling I di Universitas Jambi. Teraputik: Jurnal Bimbingan dan Konseling, 5(1), pp. 01-10. DOl: $10.26539 /$ teraputik.51458

(c) (i) This is an open distributed under the Creative Commons 4.0 Attribution License, which permits unrestricted use, distribution, and reproduction in any medium provided the original work is properly cited. (c) 2021, Sarman, F \& Asradi(s).

\begin{abstract}
Abstrak: Penelitian ini merupakan penelitian tindakan kelas dengan tujuan penelitian ini adalah untuk mendeskripsikan penerapan bahan ajar hasil pengembangan materi mata kuliah instrumentasi dalam konseling I pada pembelajaran instrumentasi dalam konseling I sebagai pendukung pemahaman konsep dan praktik di program studi bimbingan dan konseling Fakultas keguruan dan Ilmu Pendidikan Universitas Jambi. Sampel penelitian ini adalah mahasiswa kelas R003 yang mengontrak mata kuliahn isntrumentasi dalam konseling I. Instrumen dalam pengumpulan data dalam penelitian ini yaitu lembar observasi kegiatan mahasiswa selama perkuliahan. Hasil penelitian ini menunjukkan adanya peningkatan dalam setiap siklus. Pada siklus pertama pertemuan pertama dengan rata-rata persentase $50 \%$, pertemuan kedua dengan rata-rata persentase $74 \%$ dan pada siklus kedua pertemuan pertama dengan rata-rata persentase $79 \%$, pertemuan kedua $87 \%$. Berdasarkan skala pemahaman terhadap materi perkuliahan mencapai persentase sebesar $94,01 \%$ dengan makna sangat tinggi. Artinya, bahan ajar hasil pengembangan dapat membantu pemahaman konsep dan praktik mahasiswa dalam perkuliahan bimbingan dan konseling FKIP Univesitas Jambi.
\end{abstract}

Kata Kunci: Bahan Ajar, Instrumentasi, Konseling

Abstract: This research is a classroom action research with the aim of this research is to describe the application of teaching materials resulting from the development of instrumentation subject material in counseling I as a support for understanding concepts and practices in the guidance and counseling study program of the Faculty of Teacher Training and Education, Jambi University. The sample of this study were students of class R003 who contracted the instrumentation course in counseling $I$. The instrument in data collection in this study is the student activity observation sheet during lectures. The results of this study indicate an increase in each cycle. In the first cycle, the first meeting with an average percentage of $50 \%$, the second meeting with an average percentage of $74 \%$ and in the second cycle the first meeting with an average percentage of $79 \%$, the second meeting was $87 \%$. Based on the scale of understanding of the lecture material, it reaches a percentage of $94.01 \%$ which means very high. It means that the development results of teaching materials can help understanding the concepts and practices of students in the guidance and counseling lectures of FKIP Jambi University.

Keywords: Teaching Materials, Instrumentation, Counseling

\section{Pendahuluan}

Layanan bimbingan dan konseling merupakan bagian yang integral dalam dunia pendidikan. Pengembangan kompetensi peserta didik tidak hanya mengandalkan pembelajaran mata pelajaran tetapi perlu juga bantuan yang bersifat psiko-edukatif melalui pelayanan bimbingan dan konseling (Permendikbud 111, 2014). Bimbingan konseling disamping membantu pengembangan potensi peserta didik juga membantu menangani permasalahan yang dihadapi peserta didik dengan menggunakan berbagai layanan dan kegiatan pendukung layanan.

Salah satu kegiatan pendukung layanan bimbingan dan konseling guna membantu pendalaman terhadap diri dan problema yang dialami peserta didik yaitu kegiatan instrumentasi. Instrumentasi dalam kegiatan Bimbingan dan Konseling (BK) merupakan salah satu kegiatan pendukung untuk membantu terlaksananya proses pemberian bantuan kepada siswa asuh 
2 Implementasi bahan ajar hasil pengembangan materi mata kuliah instrumentasi dalam konseling I di Universitas Jambi

secara tepat atau sesuai dengan masalah yang dimiliki masing-masing siswa asuh. Kegiatan instrumentasi dalam Bimbingan dan Konseling merupakan suatu bentuk kegiatan pengumpulan data-data atau gambaran permasalahan klien (Ahmad, 2013). Tujuan kegiatan instrumentasi agar diperolehnya data hasil pengukuran terhadap kondisi klien (Prayitno, 2006).

Pemberian layanan bimbingan dan konseling tidak efektif apabila guru bimbingan dan konseling tidak mengenali siswa asuhnya maka dari itu guru Bimbingan dan Konseling mesti menguasai proses pelaksanaan kegiatan instrumentasi. Guru BK yang tidak menguasai dan tidak melaksanakan instumentasi akan memungkinkan terjadinya missmach dalam penyelesaian masalah klien. Maka dari itu calon guru bimbingan dan konseling perlu dilatih secara mendalam tentang instrumentasi pada bimbingan dan konseling.

Universitas Jambi pada Fakultas Keguruan dan IImu Pendidikan terdapat Program Studi Bimbingan dan Konseling yang juga merupakan Program Studi memuat sejumlah mata kuliah yang telah disiapkan untuk menghasilkan calon guru Bimbingan dan Konseling. Instrumentasi dalam konseling I merupakan salah satu mata kuliah keahlian yang ditawarkan program studi guna melatih calon guru BK dalam memahami dan mengaplikasikan kegiatan instrumentasi dalam BK.

Mata kuliah instrumentasi ini menuntut mahasiswa sebagai calon guru bimbingan dan konseling untuk dapat memiliki pemahaman dan mempu mempraktekkan kegiatan instrumentasi tersebut. Kegitan pembelajaran selama ini belum menggunakan buku ajar yang dapat digunakan sebagai buku pegangan bagi dosen dan mahasiswa dikarenakan belum adanya buku ajar yang menfokuskan kepada pembahasan mengenai mata kuliah instrumentasi dalam konseling I ini, sehingga mahasiswa maupun dosen merujuk dari berbagai sumber untuk masing-masing point pembahasan. Dosen yang mengajar hanya terfokus kepada powerpoint yang sudah disiapkan sesuai dengan Rencana Perkuliahan Semester Perkuliahan.

Masalah utama dalam proses perkuliahan ini yaitu bagaimana menciptakan kondisi yang dapat membangun interaksi antara pendidik dengan peserta didik yang didukung oleh sumber belajar yang memadai, dengan ketersediaan bahan ajar yang berkualitas dapat mendukung proses sehingga menciptakan hasil yang diinginkan sesuai dengan tujuan perkuliahan tersebut. Bahan ajar memberikan pedoman bagi pendidik untuk merencanakan, melaksanakan dan mengevaluasi pembelajaran. Pembelajaran yang efektif dan efisien dapat dicapai salah satunya dengan pengadaan bahan ajar (Setyowati, Parmin \& Widiatmoko:2013).

Disamping itu ketika mahasiswa sudah memasuki tahap Praktek Lapangan Konseling di Sekolah (PLKPS) mahasiswa kesulitan dalam pelaksanaan instrumentasi karena mereka lupa cara atau proses pelaksanaan salah satu kegiatan instrumentasi tersebut, sehingga dalam proses pelaporan kegiatan PLKPS mahasiswa tidak bisa lagi menjelaskan makna atau hasil dari kegiatan tersebut. Hal ini dikarenakan tidak adanya buku pegangan mahasiswa untuk mengulang ataupun mempelajari kembali materi-materi yang telah mereka pelajari pada perkuliaha Instrumentasi dalam Konseling I.

Berdasarkan uraian tersebut perlu pengembangan bahan ajar untuk memfasilitasi pembelajaran yang memudahkan bagi mahasiswa dalam proses perkuliahan. Berdasarkan fenomena tersebut, penelitian ini dimaksudkan untuk melakukan implementasi bahan ajar instrumentasi dalam konseling I yang telah dikembangkan oleh peneliti dengan menggunakan model pengembangan 4D ( Define, Design, Development dan Dessimination) yang diadaptasi menjadi 4P (Pendefinisian, Perancangan, Pengembangan dan Penyebaran), pengembangan ini telah melalui validasi ahli dan disesuaikan dengan karakteristik mahasiswa Program Studi BImbingan dan Konseling FKIP Universitas Jambi.

Pada tahap analisis kebutuhan bahan ajar sebelum pengembangan berada pada kategori rendah, kebutuhan secara fisik hanya mencapai 35\% dan secara materi 45\%. Setelah bahan ajar dikembangkan dan dilakukan uji ahli diperoleh informasi bahwa bahan ajar yang dikembangkan telah memenuhi syarat secara akseptabilitas dengan indeks Aiken 0.78 berada pada kategori tinggi, kemudian dilanjutkan dengan uji coba kelompok kecil pencapaian produk bahan ajar termasuk kategori tinggi atau 87,75\%, dan uji coba kelompok besar mendapatkan hasil berkategori tinggi. Berdasarkan hasil pengembangan pada penelitian sebelumnya, sebelum bahan ajar ini dijadikan buku pegangan pada program studi Bimbingan dan Konselng, peneliti 
merasa perlu melakukan uji coba langsung kepada mahasiswa guna kelayakan menjadi buku ajar yang akan dijadikan referensi bagi mahasiswa dalam perkuliahan.

\section{Metode}

Penelitian ini adalah penelitian tindakan dengan metode peneltitian tindakan kelas atau yang dikenal dengan metode Classroom Action Reserch (CAR). Adapun Subjek Penelitian ini adalah mahasiswa kelas R003 semester 2 yang telah melakukan registrasi tahun ajaran 20192020. Penelitian dilaksanakan sekitar Februari - Juli 2020. Penelitian ini dilaksanakan persiklus, satu siklus terdiri dari 2 pertemuan. Masing-masing siklus memiliki empat langkah utama yaitu: 1) rencana tindakan, 2) Pelaksanaan tindakan 3) observasi, 4) Refleksi.

Metode Pengumpulan Data, antara lain: 1) Observasi - Observasi pada penelitian ini dilakukan dengan mengamati seluruh kegiatan selama pembelajaran berlangsung dan mencatat seluruh aktifitas yang terjadi selama proses pembelajaran. 2) Dokumentasi - Terdiri dari dokumen pendukung pembelajaran berupa rencana pembelajaran semester,catatan harian, foto-foto selama kegiatan pembelajaran berlangsung. 3) Angket - Skala Pemahaman Materi pembelajaran Instrumentasi dalam Konseling I.

Instrumen yang digunakan berupa lembar pengamatan aktifitas perkuliahan mahasiswa dan skala pemamahan materi pembelajaran instrumentasi dalam konseling I. Teknik analisis data penelitian sebagai berikut. Observasi dilakukan menggunakan teknik persentase $\mathrm{x}=\frac{f}{n} \mathrm{x} 100$. Keterangan: $x=$ persentase $; f=$ frekuensi; $n=$ jumlah mahasiswa.

\section{Hasil dan Diskusi}

Penelitian ini ditujukan kepada mahasiswa semester genap tahun ajaran 2019/2020 kelas 2R001 yang mengontrak matakuliah instrumentasi dalam konseling I sebanak 34 mahasiswa. Berdasarkan pengalaman peneliti selama ini mengampu mata kulian instrumentasi dalam konseling I yang maasih menggunakan metode ceramah tanya jawab menggunakan power point tanpa adanya sumber rujukan lain karena sulitnya sumber rujukan akan materi perkuliahan tersebut sehingga proses perkuliahan masih terpusat kepada dosen dan power point.

Jumlah mahasiswa kelas 3R001 sebanyak 34 mahasiswa yang dibagi kepada 6 kelompok. Pengelompokan bertujuan untuk memudahkan mahsiswa dalam berbagi ide dan pemahaman konsep perkuliahan dengan teman sekelompoknya. Selanjutnya peneliti dengan teman sejawat menyepakati untuk melaksanakan tindakan siklus I dengan waktu 3 SKS (150 menit) dilaksanakan 2X pertemuan. Pertemuan I dan ke II dilaksanakan pada hari Kamis. Pemberi tindakan dilakukan oleh peneliti sendiri karena peneliti telah memahami instrumentasi dalam konseling I dan menggunakan bahan ajar yang telah peneliti kembangakan sebelumnya.

Sebelum pelaksanaan tindakan peneliti berdiskusi dengan tim peneliti untuk persiapan yang akan dilaksanakan pada tindakan, yaitu: 1) Merancang jadwal penelitian; 2) Merancang RPS; 3) Merancang instrumen penilaian untuk pengamatan ketika pelaksanaan perkuliahan berupa lembar observasi dosen dan mahasiswa, dari mahasiswa aspek yang diamati berupa kegiatan mahasiswa selama perkuliahan berlangsung meliputi: mengajukan petanyaan; merespon mahasiswa lain; menanggapi dan menjawab pertanyaan dosen; memperhatikan penjelasan dosen; keaktifan diskusi kelompok; keaktifan diskusi kelas; 4) Mempersiapkan bahan ajar perkuliahan.

Hasil penelitian siklus I

Peneliti dan observer menyepakati untuk melakukan siklus I pertemuan I pada tanggal 20 Februari 2020 mulai dari jam 07.30 s.d 10.00 (sebelum diberlakukannya PSBB) dengan materi bahasan yaitu observasi yang dilaksanakan selama 3 SKS. Pada tahap kegiatan pendahuluan, ketua kelompok sebagai individu yang bertanggung jawab memancing pemahaman ataupun memberikan pemahaman kepada anggotanya yang tidak paham dibantu dengan anggota lain. Tahap ini diawali dengan membuka perkuliahan dengan berupa penyampaian salam, absensi dan penyiapan kondisi kelas perkuliahan sesuai dengan kelompok yang sudah ditentukan 
sebelumnya, kemudian peneliti memancing pengetahuan mahasiswa supaya bisa termotivasi dalam perkuliahan dengan menanyakan kepada mahasiswa tentang observasi. Kemudian peneliti memberikan penguatan tentang konsep yang peneliti tanyakan sebelumnya. Kegiatan ini berlangsung selama 20 menit.

Pelaksanan kegiatan inti, tahap kegiatan ini dilaksanakan dengan langkah dosen menjelaskan materi perkulian secara umum, mahasiswa diminta untuk memperhatikan dengan sumber bahan ajar yang telah dibagikan sebelumnya. Kemudian memberikan waktu sebanyak 15 menit untuk mendiskusikan materi dalam kelompok masing-masing. Dilanjutkan dengan latihan sesuai dengan pedoman yang ada pada bahan ajar di mana setiap kelompok membuat pedoman observasi, kemudian melakukan kunjungan kelompok untuk membandingkan dan berdiskusi tentang pedoman observasi yang telah dibuat serta proses pelaksanaannya dan membicarkaan kembali didalam kelompok asing-masing hasil kunjungan kelompok. Setelah selesai semua proses tersebut salah seorang kelompok akan menjabarkan tugas kelompoknya dihadapan kelompok yang lain.

Pelaksanaan kegiatan akhir, pada kegiatan akhir ini adalah membimbing mahasiswa dalam menyimpulkan materi pekuliahan, kemudian menyimpulkan materi secara keseluruhan.

Berdasarkan hasil pengamatan aktifitas mahasiswa selama proses perkuliahan, pada aspek mengajukan pertanyaan hanya $35 \%$, menanggapi dan menajwab pertanyaan dosen hanya mencapai $29 \%$ serta keaktifan di kelas hanya mencapai $18 \%$. dan merespon mahasiswa lain mencapai $44 \%$. Aktifitas mahasiswa pada pertemuan pertama ini belum nampak aktif mengikuti perkuliahan. Untuk lebih rinci bisa dilihat pada tabel di bawah ini.

Tabel. 1. Aktifitas Mahasiswa pada Siklus Pertama Pertemuan Pertama

\begin{tabular}{lcc}
\hline \multirow{2}{*}{ Aspek yang diamati } & \multicolumn{2}{c}{34 Mahasiswa } \\
\cline { 2 - 3 } & Fre & $\%$ \\
\hline Mengajukan Pertanyaan & 12 & 35 \\
\hline Merespon mahasiswa lain & 15 & 44 \\
\hline $\begin{array}{l}\text { menaggapi dan menjawab pertanyaan } \\
\text { dosen }\end{array}$ & 10 & 29 \\
\hline Memperhatikan penjelasan dosen & 34 & 100 \\
\hline Keaktifan diskusi kelompok & 25 & 74 \\
\hline Keaktifan diskusi kelas & 6 & 18 \\
\hline Rata-rata persentase & & 50 \\
\hline
\end{tabular}

Pada tabel di atas dapat dimaknai bahwa keaktifan belajar mahasiswa pada pertemuan pertama ini belum nampak.

\section{Siklus I pertemuan ke II}

Sebelum melakukan tindakan peneliti mempersiapkan terlebih dahulu hal-hal yang diperlukan untuk pelaksanaan tindakan, seperti: 1) Merancang metode yang akan digunakan dalam proses perkuliahan. 2) Memepersiapkan instrumen menilaian kegiatan untuk pengamatan kegita pelaksanaan perkuliahan yang berupa lembar observasi untuk kegiatan dosen dan mahasiswa. 3) Merancang pertanyaan-pertanyaan yang akan diajukan untuk memancing pemahaman mahasiswa terhadap materi.

\section{Hasil Siklus I pertemuan ke II}

Pelaksanaan perkuliahan siklus I pertemuan ke II pada hari Kamis tanggal 27 Februari 2020 mulai pukul 07.30 s.d 10.00 dengan materi wawancara. Kegiatan ini dilaksanakan selama 3 SKS. Pada kegiatan pendahuluan peneliti sebagai dosen mengawali membuka perkuliahan dengan mengucapkan salam, melakukan absensi dan menyiapkan kondisi kelas, kemudian peneliti memancing pemahaman mahasiswa terhadap perkuliahan sebelumnya dengan menanyakan tentang jenis-jenis observasi dan ada yang menjawab dengan benar, kemudian peneliti menanyakan untuk mengukur pemahaman mahasiswa terhadap perkuliahan sekarang dengan menayakan tentang apa saja jenis wawancara, kemudian peneliti pemancing lagi 
pemahaman mahasiswa perbedaan antara wawancara langsung dan wawancara tidak langsung, kemudian dosen memberikan penguatan kepada mahasiswa hal ini berlangsung selama 30 menit.

Pelaksanaan kegiatan inti, pada tahap ini pertama dosen menjelaskan terlebih dahulu materi tentang wawancara kepada mahasiswa sesuai dengan bahan ajar yang telah diberikan kemudian untuk prosesdur kegiatan mengikuti prosedur latihan yang sudah dijabarkan dalam bahan ajar, pertama masing-masing individu di dalam kelompok membuat pedoman wawancara, dan menentukan objek yang akan diwawancarai berdasarkan tujuan dan pedoman yang telah disusun, pada tahap ini dosen mengarahkan wawancara kepada kakak tingkat yang sedang berada dilingkungan kampus. Kemudian seluruh mahasiswa melakukan proses wawancara tersebut selama 20 menit sudah kembali lagi ke kelompok masing-masing di dalam kelas. Kemudian praktikan mengarahkan mahasiswa untuk kembali ke kelompok masing-masing dan mengunjungi kelompok lain untuk melihat hasil kerja yang lainnya serta memberikan masukan dan ilmu baru yang didapat dimasing-masing kelompok. Setelah kunjungan kelompok selesai kemudian peneliti meminta perwakilan kelompok untuk menyampaikan format wawancara yang dibuatnya serta hasil wawancara yang di lakukan untuk disampaikan di depan kelas. Setelah kegiatan kelompok selesai kemudian peneliti memberikan penguatan tentang contoh format wawancara dan proses menyimpulkan hasil wawancara. Tahap akhir, kegiatan tahap ini dosen membimbing mahasiswa untuk menyimpukan perkuliahan.

Berdasarkan hasil pegamatan aktifitas mahasiswa dalam proses perkuliahan, pada aspek memperhatikan dosen mengalami peningkatan dengan mencapai $100 \%$. Pada apek merespon $76 \%$ pada aspek ini sudah ada peningkatan dari pertemuan sebelumnya, Kemudian keaktifan dalam kelompok $88 \%$. Kenyamanan dalam kelompok menjadi penentu bagaimana keaktifan dalam kelompok masih ada 4 orang mahasiswa yang belum aktif dan bahkan cenderung diam dan hanya duduk saja di dalam kelompok tidak berpartisipasi seperti rekan-rekannya yang lain. Untuk aspek mengajukan petanyaan ketika pembahasan materi ataupun diskusi antar kelompok dalam perkuliahan $59 \%$ dan pada aspek keaktifan dalam diskusi kelas 59\%. Untuk gambaran hasil aspek kegiatan mahasiswa dapa pertemuan ke 2 ini bisa dilihat pada tabel di bawah ini:

Tabel.2. Aktivitas Mahasiswa pada Siklus Pertama Pertemuan Ke-2

\begin{tabular}{lcc}
\hline \multirow{2}{*}{ Aspek yang Diamati } & \multicolumn{2}{c}{34 Mahasiswa } \\
\cline { 2 - 3 } & Fre & $\%$ \\
\hline Mengajukan Pertanyaan & 20 & 59 \\
\hline Merespon mahasiswa lain & 26 & 76 \\
\hline menaggapi dan menjawab pertanyaan dosen & 20 & 59 \\
\hline Memperhatikan penjelasan dosen & 34 & 100 \\
\hline Keaktifan diskusi kelompok & 30 & 88 \\
\hline Keaktifan diskusi kelas & 20 & 59 \\
\hline Rata-rata persentase & & 74 \\
\hline
\end{tabular}

Hasil refleksi dengan melihat video dan lembar pengamatan dosen kolaborator menunjukkan bahwa pelaksanaan perkulian dengan mengggunaan bahan ajar masih banyak halhal yang perlua diperbaiki baik dari segi cangkupan materi yang jabarkan, waktu menyampaikan apersepsi, bahasa dan intonasi berbicara belum jelas sehingga kurang mendapat respon dari mahasiswa, manajemen waktu dalam kegiatan kelompok, pelibatan semua mahasiswa dalam menyimpulkan pembelajaran, menstimulus mahasiswa yang masih ragu-ragu dalam bertanya dan penggunaan power point yang membuat fokus mahasiswa terpecah sehingga lebih fokus ke power point dari pada merujuk teori kepada buku

Hasil penelitian siklus II

Siklus II pertemuan I

Pada siklus ke II pertemuan I, materi penelitian yaitu sosiometri dengan indikator menyebutkan pengertian sosiometri, mempraktekkan cara pengaplikasian sosiometri dan 
6 Implementasi bahan ajar hasil pengembangan materi mata kuliah instrumentasi dalam konseling I di Universitas Jambi

mempraktekkan pengolahan sosiometri dan mempersentasikan hasil sosiometri. Siklus ini dilaksanakan pada hari Kamis tanggal 5 Maret 2020 dengan jumlah mahasiswa 34 orang.

Pelaksanaan kegiatan awal, tahap ini diawali dengan membuka perkuliahan dengan berupa penyampaian salam, absensi dan penyiapan kondisi kelas perkuliahan, kemudian peneliti memancing pengetahuan mahasiswa supaya bisa termotivasi dalam perkuliahan. Cara peneliti memancing pengetahuan mahasiswa yaitu dengan menanyakan kepada mahasiswa tentang sosiometri, pelaksanaan dan pengolahan sosiometri kemudian peneliti memberikan penguatan tentang konsep yang peneliti tanyakan sebelumnya. Kegiatan ini berlangsung selama 20 menit.

Pelaksanan kegiatan inti, tahap kegiatan ini dilaksanakan dengan langkah Dosen menjelaskan materi perkulian secara umum, mahasiswa diminta untuk memperhatikan dengan sumber bahan ajar yang telah dibagikan sebelumnya. Dilanjutkan dengan meminta mahasiswa untuk mempraktekkan pelaksanaan sosiometri di dalam kelas. Pada tahap ini mahasiswa secara individu melakukan aplikasi instrumentasi sosiometri di dalam kelas dengan objeknya adalah semua mahasiswa yang ada di dalam kelas dibimbing oleh dosen di mana dosen berlaku sebagai guru bimbingan dan konseling yang sedang melakukan kegiatan sosiometri hal ini dilakukan guna mahasiswa dapat mencontoh cara pelaksanaan sosiometri tersebut dalam kegiatan ini mahasiswa antusias melakukannya.

Kemudian meminta mahasiswa per kelompok masing-masing mengolah sosiometri kedalam bentuk tabel sosiometri dan sosiogram, Pada tahap ini mahasiswa bekerja sama dengan kelompok masing-masing dalam mengolah soiometri ke dalam bentuk tabel sosiometri dan sosiogram. Kegiatan ini dengan berpedoman kepada bahan ajar yang sudah diberikan nampak mahasiswa aktif berdiskusi didalam grup dalam pengolahan soiometri ini.

Pelaksanaan kegiatan akhir, kegiatan akhir ini adalah membimbing mahasiswa dalam menyimpulkan materi pekuliahan. Kemudian mnyimpulkan secara keseluruhan materi perkuliahan tersebut.

Berdasarkan hasil pengamatan aktifitas mahasiswa selama proses perkuliahan, maka dapat dilihat dari 6 aspek yang diamati, pada aspek mengajukan pertanyaan mengalami penurunan dari pada pertemuan sebelumnya hal ini disebabkan karena mahasiswa belum membaca materi sebelum perkuliahan. Aktifitas mahasiswa pada pertemuan pertama ini dalam ketegori positif karena sudah ada peningkatan dari pada sikus I.

Tabel.3. Aktifitas Mahasiswa pada Siklus ke-II Pertemuan Pertama

\begin{tabular}{lcc}
\hline \multicolumn{1}{c}{ Aspek yang diamati } & \multicolumn{2}{c}{34 Mahasiswa } \\
\cline { 2 - 3 } & \multicolumn{1}{c}{ Fre } & $\%$ \\
\hline Mengajukan Pertanyaan & 18 & 53 \\
\hline Merespon mahasiswa lain & 29 & 85 \\
\hline menaggapi dan menjawab pertanyaan dosen & 25 & 74 \\
\hline Memperhatikan penjelasan dosen & 34 & 100 \\
\hline Keaktifan diskusi kelompok & 30 & 88 \\
\hline Keaktifan diskusi kelas & 25 & 74 \\
\hline Rata-rata persentase & & 79 \\
\hline
\end{tabular}
nampak.

Pada tabel di atas dapat dimaknai bahwa pemahaman mahasiswa dalam hal ini sudah

\section{Siklus II pertemuan ke II}

Siklus ini dilaksanakan pada hari Kamis, 12 Maret 2020 dengan jumlah mahasiswa 34 mahasiswa. Berdasarkan hasil analisis pertemuan pada siklus ke I subjek penelitian belum menunjukkan hasil yang diinginkan, maka dari itu dilanjutkan dengan siklus ke II pertemuan ke II, dengan tema angket. Pada tahap pelaksanaan ini peneliti memulai perkuliahan dengan mengcapakan saalan dan melakukan absensi kepada mahasiswa. Tahap ini dibuka dengan mengulang pemahaman mahasiswa terhadap materi perkuliahan sebelumnya dengan menayakan bagaimana cara mengungkapkan hasil sosiometri kepada siswa dan melakukan 
apersepsi terhadap perkuliahan pertemuan hari tersebut dengan menanyakan pemahaman mahasiswa tentang angket, kegiatan ini berlangsung selama 20 menit.

Pelaksanaan Kegiatan inti, pada tahap ini peneliti meminta mahasiswa membuka bahan ajar yang sudah diberikan dan menjelaskan tentang angket tersebut, setelah diberikan pemahaman tentang angket, cara membuat angket dan pengaplikasiannya, selanjutnya peneliti meminta mahasiswa di dalam kelompok masing-masing untuk mendiskusikan dalam kelompok tentang materi tersebut berpatokan kepada bahan ajar yang sudah diberikan. Selanjutnya masing-masing individu dalam kelompok ditugaskan membuat angket dengan saling berutkar fikiran dan berdiskusi didalam kelompok masing-masing. Kemudian setelah selesai membuat angket mahasiswa diminta langsung mengaplikasikannya kepada beberapa sampel yang sesuai dengan tujuan angket tersebut dalam waktu 15 menit, kemudian kembali ke kelompok masingmasing dan mengolah hasil angket tersebut.

Pelaksanaan kegiatan Akhir, kegiatan akhir pelaksanaan tindakan, peneliti memberikan 2 pertanyaan untuk melihat pemahaman mahasiswa terhadap materi yang diberikan dan meminta mahasiswa menyimpulkan pemahaman apa yang didapat dalam materi tersebut.

Berdasarkan hasil pegamatan aktifitas mahasiswa dalam proses perkuliahan, dapat dilihat dari 6 aspek pengamatan, pada aspek mengajukan pertanyaan $76 \%$ sudah banyak mahasiswa yang berani bertanya terhadap materi perkuliahan dibandingkan dengan pertemuanpertemuan sebelumnya. Kemudian pada aspek meanggapi dan menjawab pertanyaan dosen $79 \%$ yang menunjukkan ada peningkatan dari sebelumnya, dengan pertanyaan yang di ajukan peneliti mahasiswa sudah bisa menjawab berdasarkan teori dan sumber referensi yang ada dapat dimaknai juga bahwa sanya persiapan mahasiswa untuk perkuliahan sudah disiapkan sebaik mungkin. Aspek merespon mahasiswa lain 91\%, keaktifan diskusi di dalam kelompok 94\% dan keaktifan berdiskusi di kelas $82 \%$ serta memperhatikan dosen mengalami peningkatan dari pada pertemuan sebelumnya $100 \%$ dengan rata-rata persentase sebesar $87 \%$.

Dari semua aspek dapat disimpulkan bahwasanya pemahaman mahasiswa terhadap materi perkuliahan menggunakan bahan ajar mengalami peningkatan dari siklus-siklus sebelumnya, dalam hal ini bahan ajar membantu mahasiswa dalam memahami perkuliahan. Untuk lebih jelasnya hal tersebut terjabar dalam tabel berikut ini:

Tabel. 4. Aktifitas Mahasiswa pada Siklus Pertama Pertemuan Pertama

\begin{tabular}{lcc}
\hline \multicolumn{1}{c}{ Aspek yang diamati } & \multicolumn{2}{c}{ 34 Mahasiswa } \\
\cline { 2 - 3 } & Fre & $\%$ \\
\hline Mengajukan Pertanyaan & 26 & 76 \\
\hline Merespon mahasiswa lain & 31 & 91 \\
\hline menaggapi dan menjawab pertanyaan dosen & 27 & 79 \\
\hline Memperhatikan penjelasan dosen & 34 & 100 \\
\hline Keaktifan diskusi kelompok & 32 & 94 \\
\hline Keaktifan diskusi kelas & 28 & 82 \\
\hline Rata-rata Persentase & & 87 \\
\hline
\end{tabular}

Berdasarkan hasil pengamatan menunjukkan bahwa pelaksanaan proses perkuliahan pada siklus sudah dapat dikatakan berhasil, jadi siklus II diangap sudah selesai.

Analisis penilaian aktifitas mahasiswa dalam pembelajaran pada siklus I pertemuan ke I nilai rata-rata sebesar $50 \%$ dan pertemuan ke II sebesar $74 \%$ berdasarkan refleksi pertemuan pertama, pada pertemuan kedua sudah menunjukkan perubahan. Untuk analisis penilaian aktifitas mahasiswa selama siklus ke II, diperoleh iklus ke II pertemuan pertama nilai rata-rata keaktifan mahasiswa sebesar 79\% dan pertemuan ke II 87\%.

Kenaikan terjadi pada semua aspek yang diobservasi contohnya merespon mahasiswa lain dan mengajukan pertanyaan, mahasiswa mengikuti kegiatan diskusi dengan memiliki keberanian dalam mengeluarkan pendapat, mahasiswa lebih fokus, kritis dan menajemen waktu penyelesaian tugas kelompoknnya sudah sesuai waktu yang ditentukan. Perubahan aktivitas perkuliahan mahasiswa secara keseluruahan adalah siklus I pertemuan pertama $50 \%$, pertemuan II 74\%, siklus II pertemuan I 79\%, dan pertemuan II $87 \%$. 
Pemahaman konsep dan praktek materi perkuliahan juga bisa dilihat dari skala pemahaman materi perkuliahan, pada masing-masing indikator pemahaman berada di atas ratarata $75 \%$ dapat dimaknai bahwa mahasiswa sudah memahami konsep dan praktek dari penggunaan bahan ajar dalam pembelajaran instrumentasi dalam konseling I. Untuk lebih rincinya bisa dilihat pada tabel berikut di bawah ini.

Tabel 5. Skor Pemahaman Materi Perkuliahan

\begin{tabular}{llccccccc}
\hline No & $\begin{array}{c}\text { Indikator } \\
\text { Pemahaman }\end{array}$ & Ideal & $\begin{array}{c}\text { Ter- } \\
\text { tinggi }\end{array}$ & $\begin{array}{c}\text { Teren- } \\
\text { dah }\end{array}$ & Total & rata-rata & $\begin{array}{l}\% \\
\text { rata }\end{array}$ & Ket \\
\hline 1 & Instrumentasi & 28 & 4 & 3 & 132 & 3,9 & 97,06 & ST \\
\hline 2 & Observasi & 28 & 4 & 3 & 129 & 3,8 & 94,9 & ST \\
\hline 3 & Wawancara & 28 & 4 & 3 & 132 & 3,9 & 97,1 & ST \\
\hline 4 & Angket & 28 & 4 & 3 & 123 & 3,6 & 90,4 & ST \\
\hline 5 & Sosiometri & 28 & 4 & 4 & 136 & 4 & 100 & ST \\
\hline 6 & AUM PTSDL & 28 & 4 & 3 & 121 & 3,6 & 88,97 & ST \\
\hline 7 & AUM UMUM & 28 & 4 & 3 & 122 & 3,6 & 89,71 & ST \\
\hline & & Keseluruhan & & & 895 & 26,3 & 94,01 & ST \\
\hline
\end{tabular}

Keterangan: ST: Sangat Tinggi

Hasil penelitian dan pembahasan diatas dapat disimpulkan bahwa penggunaan bahan ajar pada mata kuliah instrumentasi dalam konseling I yang telah dikembangkan efektif dalam meningkatkan pemahaman mahasiswa kepada konsep dan praktek.

\section{Pembahasan}

Penerapan bahan ajar hasil pengambangan mata kuliah instrumentasi dalam konseling I sebagai pendukung pemahaman konsep dan praktik mahasiswa yang dilakukan sebanyak 2 siklus menunjukkan bahwa adanya peningkatan pada aktifitas perkuliahan dan pemahaman mahasiswa terhadap materi perkuliahan melalui pengamatan selama proses pembelajaran.

Bahan ajar hasil pengembangan materi perkuliahan instrumentasi konseling I yang digunakan dosen dalam pembelajaran karena dengan adanya bahan ajar akan memudahkan pemahaman mahasiswa terhadap materi dan praktek dalam pembelajaran karena selama ini bahan ajar pada mata kuliah tersebut belum ada dan sangat sulit ditemukan. Perlu adanya pengembangan bahan ajar supaya proses pembelajaran dapat tercapai dengan baik efektif dan efisien, (Ibrahim dalam Harijanto, 2007). Bahan ajar yang dibuat dengan bahas yang mudah dimengerti dengan bersifat sistematis dengan harapan mereka dapat belajar secara mandiri (Budiman, 2008).

Bahan ajar yang disusun sudah dilengkapi dengan kegiatan kerja mahasiswa untuk memperdalam pemahaman dan praktek terhadap materi, sehingga akan lebih memudahkan pengguna bahan ajar dalam melakukan proses pembelajaan. Proses pembelajaran akan lebih bervariatif dan mahasiswa akan banyak berpartisipasi dalam pembelajaran mendoronag terciptanya student center learning.

Para proses pemberian perlakuan setiap siklus menunjukkan pemahaman mahasiswa terhadap materi dan praktek mingkatan terlihat dalam aktifitas perkuliahan. Pada aspek mengajukan pertanyaan, merespon mahasiswa lain dan menjawab pertanyaan dosen mengalami peningkatan setiap siklusnya hal ini didorong dengan adanya sumber-sumber bacaan yang akan dirujuk mahasiswa sebelum perkuliahan ditambah dengan sumber baku berupa bahan ajar sehingga memperkaya konsep mahasiswa. Tenaga pengajar dalam hal ini dosen hanya memberikan media penghubung untuk membantu peserta didik mencapai suatu tingkat pemahaman tetapi tetap diupayakan agar peserta didik dapat mencapai tingkat tersebut, (Nur \& Wikandri, dalam Trianto, 2010). 
Selanjutnya, hasil penelitian ini juga menunjukkan bahwa kemampuan diskusi mahasiswa dalam skala kelompok dan skala kelas juga mengalami peningkatan setiap siklusnya berdasarkan pengamatan selama pembelajaran. Hal ini menunjukkan pemahaman mahasiswa terhadap materi dan praktek dalam mata kuliah tersebut terpenuhi serta kemampuan berfikir kritis mahasiswa sudah terbangun, terlihat dari bagaimana mahasiswa memecahkan masalah maupun pertanyaan-pertanyaan yang dimunculkan rekan-rekannya sesuai dengan konsep dan teori. Apabila anak ingin mengingat sesuatu tanpa mengaitkan mengaitkan suatu hal dengan yang lainnya maka proses pembelajaran ataupun hasilnya tidak akan bermakna sama sekali hanya berupa hafalan (Bel dalam Nurhayati 2017) untuk menghindari hal tersebut perlu suatu perangkat pembelajaran yang dapat melibatkan mahasiswa secara aktif dengan gaya belajar yang lebih bermaknna.

Hasil Penelitian ini memperkaya temuan-temuan yang telah dilakukan para peneliti sebelumnya, peneliti tingkat nasional yang dilakukan Senjaharmini, dkk di Suralaga yang menemukan bahwa penggunaan bahan ajar efektif dalam meningkatkan kemampuan debat siswa (Senjaharmini, dkk: 2019). Selanjutnya temuan Mubarok \& Kartika dimana penggunaan bahan ajar lebih efektif dalam proses belajar mengajar dari pada yang tidak menggunakan bahan ajar (Mubarok \& Kartika. 2019). Selanjutnya peneliti tingkat internasional Illin \& Kutluay menemkan bahwa penggunaan bahan ajar elektronik menghemat waktu dan memicu kemauan siswa EPS (English for Specific Purposes.

Hasil analisis diatas menunjukkan bahwa penggunaan bahan ajar selain dapat meningkatkan pemahaman peserta didik terhadap materi juga efektif meningkatkan kemampuan berdebat siswa dan keefektifan waktu dalam mengajar. Berdasarkan hal tersebut dapat disimpulkan bahwa secara empiris penggunaan bahan ajar dalam proses pembelajaran dapat meningkatkan pemahaman konsep siswa terhadap materi pembelajaran.

\section{Simpulan}

Berdasarkan penelitian yang telah dilakukan dapat diambil kesimpulan sebagai berikut. Pertama, Penggunaan bahan ajar hasil pengembangan materi mata kuliah instrumentasi dalam konseling I dapat meningkatkan pemahaman konsep mahasiswa. Kedua, ada peningkatan pemahaman mahasiswa terhadap konsep materi perkuliahan. Pada siklus I dengan total skor rata rata persentase $62 \%$ pada siklus 2 menunjukkan adanya pengingkatan degan rata-rata persentase $83 \%$ artinya ada peningkatan sebesar $21 \%$.

\section{Ucapan Terima Kasih}

Ucapan terima kasih disampaikan kepada mahasiswa Universitas Jambi sebagai partisipan dalam penelitian ini.

\section{Daftar Rujukan}

Ahmad, Riska. (2013). Dasar-dasar Bimbingan dan Konseling. Padang: UNP Press.

Budiman, I, Sukandi, A, Setiawan, A. (2008). Model Pembelajaran Multimedia Interaktif

Dualisme Gelombang Partikel untuk Meningkatkan Pemahaman Konsep dan

Ketertampilan Berfikir Kritis. Jurnal Penelitian Pendidikan IPA, 2 (1), 17-21.

Harijanto, M. (2007). Pengembangan Bahan Ajar untuk Peningkatan Kualitas Pembelajaran

Program Pendidikan Pembelajar Sekolah Dasar. Journal Didaktika, Vol.2 No.1 Maret 2007: 216-226

Illin, Kutlu \& Kutluay. (2013). An Action Research: Using Videos for Teaching Grammar in an

ESP Class. Journal Social and Behavioral Sciences $70272-28$.

Kemendikbud. (2014). Permendikbud 111 Tahun 2014 tentang Bimbingan Konseling. Jakarta:

Kementerian Pendidikan dan Kebudayaan. 
Mubarok, I.W \& Kartika, P. C. (2019). Efektifitas Penggunaan Bahan Ajar Berbasis Android Nemo Bahasa Indonesia untuk Mahasiswa BIPA Tingkat Pemula Program Darmasiswa Universitas Muhammadiyah Surabaya. METALINGUA. Jurnal pendidikan Bahasa dan Sastra Indonesia. Volume 4 No. 1. https://doi.org/10.21107/metalingua.v4i1.6124.

Nurhayati, N. (2017). Pengembangan Bahan Ajar Trigonometri Berbasis Kontekstual Melalui Metode Guided Discovery Untuk Meningkatkan Pemahaman Konsep Mahasiswa. Jurnal Pendidikan Matematika dan Matematika. Vol. 3 (1), pp: 31-44. https://doi.org/10.24853/fbc.3.1.31-44

Prayitno. (2006). Spektrum dan Keprofesian Pelayanan Profesi Konseling. FKIP Universitas Negeri Padang.

Senjaharmini, dkk. (2019). Efektivitas Bahan Ajar IPA Berbasis Inkuiri Terbimbing (BAIPABIT) untuk Meningkatkan Kemampuan Berargumen Peserta Didik. Journal Pijar MIPA, Vol. 14 No. 2 :55 -59. http://dx.doi.org/10.29303/jpm.v14i2.1286.

Setyowati, R., Parmin \& Widiatmoko, A. (2018). Pengembangan Modul IPA Berkarakter Peduli Lingkungan Tema Polusi Sebagai Bahan Ajar Siswa SMK N 11 Semarang. Journal (Vol. 2). Unnes Science Education Journal. DOI. 10.15294/usej.v2i2.2031.

Trianto. (2010). Model Pembelajaran Terpadu.(Konsep, Strategi, dan Implementasinya dalam Kurikulum Tingkat Satuan Pendidikan). Jakarta: Bumi Aksara.

\section{Competing interests:}

The authors declare that they have no significant competing financial, professional or personal interests that might have influenced the performance or presentation of the work described in this manuscript. 